\title{
Labia Minora Carcinoma
}

National Cancer Institute

\section{Source}

National Cancer Institute. Labia Minora Carcinoma. NCI Thesaurus. Code C9364.

A carcinoma that arises from the labia minora. 